\title{
NOTES
}

\section{CONSTITUTIONAL LAW: CONSTITUTIONALITY OF RELIGIOUS QUALIFICATIONS FOR STATE PUBLIC OFFICE}

The United States Supreme Court recently considered, for the first
time, the constitutionality. of a religious qualification for state public
office. ${ }^{1}$ In Torcaso v. Watkins, ${ }^{2}$ plaintiff was denied a commission as a
notary public because of his refusal to declare a belief "in the existence of
God" as required by the Maryland Constitution. The Maryland Court
of Appeals rejected plaintiff's contention that the oath requirement vi-
olated the federal constitution. On appeal, the United States Supreme
Court unanimously" held that Maryland's requirement of a declaration
of belief as a prerequisite for holding public office violated the guarantees
of religious freedom embodied in the first and fourteenth amendments.

${ }^{2}$ Eight states now have religious tests for public office. ARx. Const. art. 19, § I (but see art. 2, \$26); MD. Const., Declaration of Rights art. 37; Miss. Const. art. $14, \S 265$; N.C. Const. art. $6, \S 8$; PA. Const. art. I, $\$ 4$; S.C. Const. art. 17 , § 4 ; TENN. Const. art. 9, § 2 ; Tex. Const. art. I, § 4 .

${ }_{367}$ U.S. 488 ( 1961 ).

3 "[N]o religious test ought ever to be required as a qualification for any office of profit or trust in this State, other than a declaration of belief in the existence of God." Declaration of Righis art. 37. The Maryland Court of Appeals construed this provision to be self-executing and the oath to be mandatory. Torcaso v. Watkins, 223 Md. 49, 55, 162 A.2d 438, 441 ( 1960 ), rev'd, 367 U.S. 488 (1961).

Ibid.

${ }^{5}$ Justices Frankfurter and Harlan concurred in the result but did not join in the opinion. For a statement of their views on the meaning of the "establishment" clause, see McGowan v. Maryland, 366 U.S. 420, 460-70 (196I) (Frankfurter, J. dissenting, joined by Harlan, J.).

- "Congress shall make no law respecting an establishment of religion, or prohibiting the free exercise thereof ..." U.S. Const, amend. I. For many years the first amendment was construed to apply only to the federal government. It is now settled that the fourteenth amendment makes the first applicable to the states also. McGowan v. Maryland, supra note 5, at 429; Joseph Burstyn, Inc. v. Wilson, 343 U.S. 495, 500 (1951); Murdock v. Pennsylvania, 319 U.S. 105, 108 (1943); Chaplinsky v. New Hampshire, 315 U.S. 568, 570-7I (1942); Cantwell v. Connecticut, 3 10 U.S. 296, $303(1940)$.

Article VI of the Constitution provides, inter alia, that "no religious Test shall ever be required as a Qualification to any Office or public Trust under the United States." This clause has never been applied to the states. Torcaso v. Watkins, 223 Md. 49, 57,162 A.zd 438, 442 (1960), rév'd, 367 U.S. 488 (xg6r); Bond v. Bond, 144 W. Va. 478, rog S.E.2d 16, 23. (1959). The Supreme Court declined to consider 
Freedom of religion, as expressed in the first amendment, has been interpreted by the Supreme Court to embrace the twin concepts of freedom to believe and freedom to act. ${ }^{7}$ Certain governmental infringements upon freedom of action imposed in the interest of the health, morals, or peace of society have withstood the Court's scrutiny. ${ }^{8}$ At the same time, the Court has declared freedom of belief to be absolute. ${ }^{9}$ However, prior to Everson v. Board of Education ${ }^{10}$ the Supreme Court never faced the issue of whether the first amendment gave protection to non-believers equal to that given believers. ${ }^{11}$

Since Everson the "establishment" clause has become the major issue in religious freedom cases, requiring the Supreme Court to determine whether the prohibition against "an establishment of religion" refers

the applicability of article VI to the states in Torcaso v. Watkins. 367 U.S. at 489 , n.I.

7 Cantwell v. Connecticut, supra note 6, at 303 .

"It is ... clear that a State may by general and non-discriminatory legislation regulate the times, the places, and the manner of soliciting upon its streets, and of holding public meetings thereon; and may in other respects safeguard the peace, good order and comfort of the community, without unconstitutionally invading the liberties protected by the Fourteenth Amendment." Id. at 304 .

See McGowan v. Maryland, 366 U.S. 420 (296I) (Sunday closing laws); Prince v. Massachusetts, 321 U.S. 158 (1944) (prohibition against children selling religious literature in the streets); Davis v. Beason, 133 U.S. 333 ( 1890 ) (disenfranchisement of bigamists); Reynolds v. United States, 98 U.S. 145 ( 1878 ) (prohibition of bigamy).

- American Communications Ass'n v. Douds, 339 U.S. 382, 393 (1950) (dictum while upholding requirement of denial of belief in overthrow of government); Cantwell v. Connecticut, 3 ro U.S. 296, 304 (1940) (dictum). See Speiser v. Randall, 357 U.S. 513, 535-36 (1958) (concurring, opinion); Everson v. Board of Education, 330 U.S. I, 15-16, 18 (1947) (dictum); United States v. Ballard, 322 U.S. 78 (1944) (jury cannot pass on validity of beliefs); Reynolds v. United States, 98 U.S. 145, I 64 (1878) (dictum).

10 330 U.S. I (1 947 ).

1 The religious freedom cases prior to that time involved believers who were trying to enforce the right to free exercise of their religion. E.g., United States v. Ballard, 322 U.S. 78 (1944); Cantwell v. Connecticut, 310 U.S. 296 ( 1940); Reynolds v. United States, 98 U.S. 145 ( 1878 ).

Some states apparently have made a distinction between believers and non-believers as regards religious freedom. Compare ARK. Const. art. 2, \$26, which declares that "no religious test shall ever be required of any person as a qualification to vote or hold office, nor shall any person be rendered incompetent to be a witness on account of his religious belief. ..." with art. 19, § 1, which states that "no person who denies the being of a God shall hold any office in the civil departments of this State, nor be competent to testify as a witness in any court." The apparent contradiction is resolved only by excluding disbelief from the freedom of religious belief.

See Torcaso v. Watkins, 223 Md. 49, 59, I62 A.2d 438, 443 (1960), rev'd, 367 U.S. 488 (1961), where, according to the Maryland court: "The historical record makes it clear that religious toleration, in which this State has taken pride, was never thought to encompass the ungodly." 
to a particular sect only or to religion in general. ${ }^{12}$ Implicit in the determination of that question is a decision as to whether the freedom of belief applies only to believers.

In Everson the Supreme Court considered a New Jersey statute under which a local school reimbursed parents of children attending parochial schools, as well as parents of children attending public schools, for the cost of riding public buses to school. After holding that the statute was not an unconstitutional aid to religion, Mr. Justice Black, speaking for the majority, emphasized in dicta that the state must be neutral in its relations with religious believers and non-believers. ${ }^{13}$ Furthermore, he said that the state could not exclude non-believers from the benefits of public welfare legislation merely because of their lack of belief; $;^{14}$ nor could it force them to express a belief or punish them for professing disbelief. ${ }^{15}$ Such actions by the state would violate the "establishment" clause by giving preference to religion over secularism.

In Illinois ex rel. McCollum v. Board of Education ${ }^{16}$ the Supreme Court invalidated a program of released time for religious instruction in public schools. The Court explicitly rejected the contention that the first amendment did not prevent impartial government aid to all religions. ${ }^{17}$ However, no specific reference was made to non-belief, except for reaffirmation of the famous Everson dicta. ${ }^{18}$ The McCollum decision might have settled the meaning of the "establishment" clause as an absolute prohibition against any preference of religion, had the

\footnotetext{
${ }^{22}$ See generally Pfeffer and O'Neil, The Meaning of the Establishment ClauseA Debate, 2 Bufralo L. Rev. 225 (1953); Symposium, Religion and the State, 14 LAW \& Contemp. Prob. I-1 43 (1949).

18 "That [the First] Amendment requires the state to be a neutral in its relations with groups of religious believers and non-believers. ..." Everson $\%$. Board of Education, 330 U.S. I, 18 (1947) (dictum).

14 "[New Jersey] cannot exclude individual Catholics, Lutherans, Mohammedans, Baptists, Jews, Methodists, Non-Believers, Presbyterians, or the members of any other faith, because of their faith, or lack of it, from receiving the benefits of public welfare legislation." Id. at 16.

16 "The 'establishment of religion' clause of the First Amendment means at least this: Neither a state nor the Federal Government . . . can pass laws which aid one religion, aid all religions, or prefer one religion over another. Neither can force nor influence a person ... to profess a belief or disbelief in any religion. No person can be punished for entertaining or professing religious beliefs or disbeliefs. ... Neither a state nor the Federal Government can, openly or secretly, participate in the affairs of any religious organizations or groups and vice versa." Id. at 15-16.

${ }_{10} 333$ U.S. 203 (1948) (opinion of Black, J.).

${ }^{17}$ Id. at $210-11$. See note 15 supra.

${ }^{18}$ Id. at 211 . See note 15 supra.
} 
Court not injected new doubt by upholding a different type of released time program three years later in Zorach $v$. Clauson. ${ }^{10}$ Speaking for the majority in Zorach, Mr. Justice Douglas made the oft-quoted ${ }^{20}$ statement: "We are a religious people whose institutions presuppose a Supreme Being." In their dissents, Justices Black, Frankfurter, and Jackson voiced strong objections to what appeared to them to be an omission of non-belief from the protection of the first amendment. ${ }^{22}$

The unanimous decision in Torcaso $v$. Watkins seems finally to have settled the status of non-believers under the first amendment. Maryland's religious test for public office was found to be an unconstituitonal invasion of plaintiff's "freedom of belief and religion."23 Since the plaintiff did not claim to profess any particular belief or to belong to any religion, ${ }^{24}$ the instant case, in effect, recognizes the right to disbelieve and to disregard religion. ${ }^{25}$

The immediate effect of Torcaso is to invalidate state constitutional provisions limiting officeholding to those who believe in God. ${ }^{26}$ More-

343 U.S. 306 (1952).

${ }^{20}$ E.g., Torcaso v. Watkins, 223 Md. 49, 58, 162 A.2d 438, 443 (1960) (dictum), rev'd, $3_{67}^{6}$ U.S. 488 (1961); Engel v. Vitale, to N.Y.2d 174, 181, 176 N.E.2d 579, 583,218 N.Y.S.2d 659, 661 (concurring), cert. grasted, 368 U.S. 924 (196I).

${ }_{21}$ Zorach v. Clauson, 343 U.S. 306, 313 (1952) (dictum). But see McGowan v. Maryland, 366 U.S. 420, 563-64 (1961), where Mr. Justice Douglas expressly includes agnostics and atheists within the protection of the first amendment.

22 "Before today, our judicial opinions have refrained from drawing invidious distinctions between those who believe in no religion and those who do believe. The First Amendment has lost much if the religious follower and the atheist are no longer to be judicially regarded as entitled to equal justice under law." Zorach v. Clauson, supra note 21 , at 320 (Black, J. dissenting). "The day that this country ceases to be free for irreligion it will be free for religion. ..." Id. at 325 (Jackson, J. dissenting). Mr. Justice Frankfurter joined in the Jackson dissent.

${ }^{28}{ }_{367}$ U.S. at 496 .

"See Brief for Appellant, pp. 18,$41 ; 46$.

${ }^{28}$ The right to disbelieve is derived from the Supreme Court's postulate that no state may exercise its authority to aid all religions as against non-believers or to prefer God-oriented religions over non-deistic religions. Torcaso v. Watkins, ${ }_{3} 67$ U.S. 488, 495 ( $196 \mathrm{I}$ ). If a state cannot discriminate in favor of those who believe in God, non-believers are protected from governmental imposition of civil disabilities because of their disbelief. Otherwise, "the power and authority of the State . . . [would be] put on the side of one particular sort of believers-those who are willing to say they believe in "the existence of God." "Id. at 490. Compare Speiser v. Randall, 357 U.S. 513, 518-19 (1958).

See McGowan v. Maryland, 366 U.S. 420, 564 (196I) (Douglas, J. dissenting) (first amendment includes "freedom from religion"); West Virginia Bd. of Educ. v. Barnette, 3 I9 U.S. 624, 645 (1943) (Murphy, J. concurring) (freedom to refrain from speaking).

${ }^{20}$ The Maryland provision is the only one which requires an actual declaration of 
over, the decision evokes serious doubt as to the constitutionality of religious qualifications for witnesses in court. ${ }^{27}$ The greatest significance of Torcaso, however, is that it clearly establishes that the first amendment protects the beliefs and practices of those who have no religion or whose religion includes no concept of God to the same extent that it protects members of deistic religions. In so holding the decision lends impressive weight to the proposition that freedom of belief is absolute.

belief (see authorities cited in note $x^{\prime \prime}$ supra), but that distinction became insignificant when the Court held that the "religious test" was unconstitutional.

${ }^{27}$ For a discussion of religious oaths for witnesses see 6 Wigmore, Evidence $\$ \S$ 1815-29 (3d ed. 1940). Only Arkansas, Maryland, and North Carolina require a belief in God. 